\title{
JEKK
}

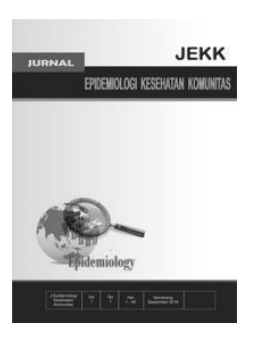

\section{Faktor-Faktor yang Berhubungan dengan Tingkat Kecemasan pada Tenaga Kesehatan pada Masa Pandemi COVID-19 (Studi di RSUD Dr. Moewardi Surakarta)}

\author{
Rani Wijayanti*, Retno Hestiningsih*, Sri Yuliawati*, Nissa Kusariana* \\ "Bagian Epidemiologi dan Penyakit Tropik Fakultas Kesehatan Masyarakat \\ Universitas Diponegoro
}

\begin{abstract}
Background: When the COVID-19 pandemic occurred, healthcare workers were under pressure, especially those who had direct contact with confirmed cases of COVID-19 due to the high risk of infection. These factors can lead to increased psychological problems in health workers such as anxiety. Therefore, it is necessary to analyze the factors that can cause anxiety during the COVID19 pandemic. In this research was conducted at RSUD Dr. Moewardi Surakarta.

Methods: This study used a cross-sectional study design. The sample size in this study was 103 respondents. The sampling technique used was purposive sampling.

Result: The results of this study indicate that the factors associated with the level of anxiety are age ( $\mathrm{p}$-value $=0.037)$, gender $(\mathrm{p}$-value $=0.003)$, and years of service $(\mathrm{p}$-value $=0.023)$. Factor that is not related to the level of anxiety is marital status ( $\mathrm{p}$-value $=0.830)$.

Conclusion : It can be concluded that age, gender, years of service are factors related to the level of anxiety in health workers at RSUD Dr. Moewardi Surakarta.
\end{abstract}

Keywords: Anxiety; Healthcare Worker; COVID-19.

\footnotetext{
*Penulis korespondensi, ranijay18@gmail.com
} 


\section{Pendahuluan}

COVID-19 (Coronavirus Disease 2019) disebabkan oleh SARS-CoV-2 (Severe Acute Respiratory Syndrome Coronavirus 2) yang merupakan penyakit yang menular jenis baru. ${ }^{1}$ Orang-orang akan mengalami gejala sakit pernapasan ringan hingga sedang jika telah terkena infeksi COVID-19. ${ }^{2}$ COVID-19 ditularkan secara kontak langsung dengan tetesan pernapasan melalui batuk maupun bersin dari orang yang telah terinfeksi dan menyentuh benda yang terkontaminasi dengan virus.

COVID-19 dilaporkan pertama kali pada tanggal 8 Desember 2019 di Provinsi, Hubei, China. Jumlah kasus yang terinfeksi akibat COVID-19 yang telah dikonfirmasi menunjukkan tingkat keparahan wabah infeksi yang mengakibatkan virus menyebar dengan cepat. $^{3}$ Di Indonesia, kasus pertama COVID-19 di umumkan pada tanggal 2 Maret 2020 dan kasus ini meningkat setiap harinya. ${ }^{4}$

Tenaga kesehatan di seluruh dunia telah mendapatkan tekanan akibat pandemi COVID-19. Tenaga kesehatan sebagai garda terdepan yang merawat pasien dengan COVID-19. Setiap hari, mereka menghadapi risiko tinggi terinfeksi dan dihadapkan pada shift kerja yang panjang. ${ }^{5} 6$

Tenaga kesehatan saat pandemi COVID-19 menghadapi berbagai tantangan dalam merawat pasien dengan COVID-19 yaitu mengurangi penyebaran infeksi, mengembangkan strategi jangka pendek yang sesuai, dan membuat rencana jangka panjang.

Seluruh tenaga kesehatan yang menghadapi tekanan akibat COVID-19, terutama yang berhubungan dengan kasus terkonfirmasi COVID-19 yang dikarenakan risiko infeksi yang tinggi, APD yang kurang memadai, kurangnya pengalaman dalam mengelola dan mengendalikan penyakit, waktu kerja yang lebih lama, munculnya stigma yang akibat berada di lingkungan COVID-19, dan dukungan sosial dari lingkungan sekitar yang masih kurang. Faktor-faktor tersebut dapat mengakibatkan masalah psikologis meningkat pada tenaga kesehatan seperti kecemasan, ketakutan, insomnia, dan depresi yang pada akhirnya dapat berpengaruh pada kerja. Beban psikologis dan kesehatan tenaga kesehatan secara keseluruhan telah mengalami kelelahan secara emosional, yang dapat menyebabkan kurang maksimalnya dalam merawat pasien. ${ }^{7}$

World Health Organization (WHO) menyatakan bahwa, kesehatan mental merupakan keadaan sejahtera setiap individu menyadari akan potensi dirinya sendiri, dapat mengatasi tekanan pada hidup yang normal, dapat produktif dalam bekerja dan memberikan manfaat, serta dapat memberikan sebuah kontribusi untuk masyarakat. ${ }^{8}$

Gangguan pada kesehatan mental awalnya muncul dari adanya rasa cemas. Pada tingkat tertentu kecemasan dapat membuat seseorang menjadi lebih waspada dan berhatihati terhadap suatu ancaman. Dikarenakan dengan adanya pandemi Covid-19, diperlukan mengelola kecemasan dengan baik sehingga tetap memberikan awareness tetapi tidak sampai menimbulkan panik yang terlalu tinggi atau hingga membuat gangguan pada kesehatan mental yang lebih buruk. ${ }^{9}$

Berdasarkan pada uraian masalah di atas, maka tujuan dari penelitian ini adalah untuk menganalisis faktor-faktor yang berhubungan dengan tingkat kecemasan pada tenaga kesehatan di RSUD Dr. Moewardi Surakarta.

\section{Metode}

Penelitian ini merupakan penelitian observasional analitik dengan pendekatan desain studi cross-sectional untuk menganalisis faktor-faktor yang berhubungan dengan tingkat kecemasan pada tenaga kesehatan. Dalam penelitian ini yang menjadi variabel terikat adalah tingkat kecemasan dan variabel bebas adalah usia, jenis kelamin, jenis pekerjaan, status pernikahan, dan masa kerja. Penelitian ini dilaksanakan di RSUD Dr. Moewardi Surakarta pada bulan Maret hingga November 2021. 
Populasi dalam penelitan ini adalah tenaga kesehatan diantaranya dokter, perawat, bidan, pranata laboratorium dan nutrisonis yang bekerja di RSUD Dr. Moewardi berjumlah 1329 orang. Besar sampel diambil menggunakan rumus Lemeshow diperoleh jumlah sampel minimal sejumlah 103 responden.

Teknik pengambilan sampel yang digunakan adalah purposive sampling. Teknik pengambilan sampel dengan cara menentukan kriteria khusus yang sesuai dengan tujuan penelitian sehingga diharapkan dapat menjawab permasalahan penelitian.

Analisis data yang digunakan adalah analisis univariat dan analisis bivariat. Untuk uji hubungan yang digunakan dalam penelitian ini adalah uji korelasi Spearman. Tingkat kecemasan diukur menggunakan Zung Self-rating Anxiety Scale (ZSAS).

\section{Hasil}

\section{Karakteristik Responden}

Tabel 1. Distribusi Karakteristik Responden

\begin{tabular}{ccc}
\hline $\begin{array}{c}\text { Karakteristik } \\
\text { Responden }\end{array}$ & Frekuensi & Persentase (\%) \\
\hline Usia & & \\
$17-25$ & 10 & 9,7 \\
$26-35$ & 43 & 41,7 \\
$36-45$ & 27 & 26,2 \\
$46-55$ & 20 & 19,4 \\
$56-65$ & 3 & 2,9 \\
Jenis Kelamin & & \\
Laki-laki & 31 & 30,1 \\
Perempuan & 72 & 69,9 \\
$\quad$ Status & & \\
Pernikahan & & \\
Belum menikah & 11 & 10,7 \\
Menikah & 92 & 89,3 \\
Masa Kerja & & \\
< 6 tahun & 24 & 23,3 \\
$6-10$ tahun & 34 & 33 \\
$>10$ tahun & 45 & \\
\hline
\end{tabular}

$(69,9 \%)$ lebih banyak dibandingkan responden yang berjenis kelamin laki-laki $(30,1 \%)$. sebagian besar pekerjaan responden adalah perawat $(36,9 \%)$, sedangkan responden yang pekerjaannya paling sedikit adalah dokter $(7,9 \%)$. Responden yang sudah menikah $(89,3 \%)$ lebih banyak dibandingkan responden yang belum menikah (10,7\%). Sebagian besar responden memiliki masa kerja lebih dari 10 tahun $(43,7 \%)$.

\section{Gambaran Tingkat Kecemasan}

Tabel 2. Distribusi Tingkat Kecemasan Responden

\begin{tabular}{lcc}
\hline Tingkat Kecemasan & Frekuensi & $\begin{array}{c}\text { Persentase } \\
(\boldsymbol{\%})\end{array}$ \\
\hline Kecemasan ringan & 50 & 48,5 \\
Kecemasan sedang & 53 & 51,5 \\
\hline
\end{tabular}

Berdasarkan tabel 2 diketahui bahwa responden lebih banyak mengalami kecemasan sedang (51,5\%) dibandingkan dengan kecemasan ringan $(48,5 \%)$.

\section{Hasil Analisis Bivariat}

a. Usia

Berdasarkan tabel 3 diketahui bahwa didapat hasil uji statistik dengan nilai $\mathrm{p}=0,037(\mathrm{p}<0,05)$ sehingga dapat disimpulkan terdapat hubungan antara usia dengan tingkat kecemasan.

b. Jenis Kelamin Berdasarkan tabel 3 diketahui bahwa didapat hasil uji statistik dengan nilai $\mathrm{p}=0,003(\mathrm{p}<0,05)$ sehingga dapat disimpulkan terdapat hubungan antara jenis kelamin dengan tingkat kecemasan.
Berdasarkan tabel 1 diketahui bahwa responden yang kelompok usianya 26 - 35 tahun lebih banyak $(41,7 \%)$ dan paling sedikit pada kelompok usia 56 - 65 tahun $(2,9 \%)$. Responden yang berjenis kelamin perempuan 
c. Status Pernikahan

Berdasarkan tabel 3 diketahui bahwa didapat hasil uji statistik dengan nilai $\mathrm{p}=0,830(\mathrm{p}>0,05)$ sehingga dapat disimpulkan tidak terdapat hubungan antara status pernikahan dengan tingkat kecemasan. d. Masa Kerja

Berdasarkan tabel 3 diketahui bahwa didapat hasil uji statistik didapat nilai $\mathrm{p}=0,023(\mathrm{p}<0,05)$ sehingga dapat disimpulkan terdapat hubungan antara masa kerja dengan tingkat kecemasan tenaga kesehatan RSUD Dr. Moewardi.

Tabel 3 Analisis Faktor-Faktor Yang Berhubungan Dengan Tingkat Kecemasan

\begin{tabular}{|c|c|c|c|c|c|c|c|c|}
\hline \multirow{3}{*}{$\begin{array}{c}\text { Karakteristik } \\
\text { Responden }\end{array}$} & \multicolumn{6}{|c|}{ Tingkat Kecemasan } & \multirow{3}{*}{ p-value } & \multirow{3}{*}{ Keterangan } \\
\hline & \multicolumn{2}{|c|}{ Ringan } & \multicolumn{2}{|c|}{ Sedang } & \multicolumn{2}{|c|}{ Total } & & \\
\hline & f & $\%$ & $\mathbf{f}$ & $\%$ & $\mathbf{F}$ & $\%$ & & \\
\hline \multicolumn{9}{|l|}{ Usia } \\
\hline $17-25$ & 3 & 6 & 7 & 13,2 & 10 & 9,7 & \multirow{5}{*}{0,037} & \multirow[t]{5}{*}{ Berhubungan } \\
\hline $26-35$ & 18 & 36 & 25 & 47,2 & 43 & 41,7 & & \\
\hline $36-45$ & 14 & 28 & 13 & 24,5 & 27 & 26,2 & & \\
\hline $46-55$ & 14 & 28 & 6 & 11,3 & 20 & 19,4 & & \\
\hline $56-65$ & 1 & 2 & 2 & 3,8 & 3 & 2,9 & & \\
\hline \multicolumn{9}{|l|}{ Jenis Kelamin } \\
\hline Laki-laki & 22 & 71 & 9 & 29 & 31 & 100 & \multirow[t]{2}{*}{0,003} & \multirow[t]{2}{*}{ Berhubungan } \\
\hline Perempuan & 28 & 38,9 & 44 & 61,1 & 72 & 100 & & \\
\hline \multicolumn{8}{|l|}{ Status Pernikahan } & \multirow{4}{*}{$\begin{array}{c}\text { Tidak } \\
\text { Berhubungan }\end{array}$} \\
\hline Belum menikah & 5 & 45,5 & 6 & 54,4 & 11 & 100 & \multirow[t]{2}{*}{0,830} & \\
\hline Menikah & 45 & 51,1 & 47 & 51,1 & 92 & 100 & & \\
\hline \multicolumn{8}{|l|}{ Masa Kerja } & \\
\hline$<6$ tahun & 9 & 37,5 & 15 & 62,5 & 24 & 100 & \multirow{3}{*}{0,023} & \multirow{3}{*}{ Berhubungan } \\
\hline $6-10$ tahun & 13 & 38,2 & 21 & 61,8 & 34 & 100 & & \\
\hline$>10$ tahun & 28 & 62,2 & 17 & 37,8 & 45 & 100 & & \\
\hline
\end{tabular}

\section{Pembahasan}

Usia dianggap menjadi dasar kematangan dan perkembangan seseorang. ${ }^{10}$ Dikarenakan kematangan atau maturitas usia suatu individu akan mempengaruhi kemampuan koping seseorang. ${ }^{11}$ Pada penelitian yang dilakukan, jumlah responden yang memiliki kecemasan paling banyak yaitu pada kelompok usia 26 - 35 tahun. Penelitian ini sejalan dengan penelitian yang dilakukan oleh Lei Huang pada tahun 2020 bahwa ada hubungan antara usia dengan tingkat kecemasan $(\mathrm{p}=0,011)$ dan pada peneltian tersebut ditemukan bahwa dengan bertambahnya usia, tingkat kecemasan tenaga medis yang berisiko tinggi terpapar radiasi juga meningkat. ${ }^{12}$
Jenis kelamin merupakan faktor yang dapat mempengaruhi kecemasan secara signifikan. Dalam suatu penelitian disebutkan bahwa perempuan lebih berisiko mengalami kecemasan dibandingkan dengan laki-laki. ${ }^{13}$ Perempuan juga memiliki sifat lebih sensitif atau peka terhadap suatu keadaan. Pada penelitian yang dilakukan, sejalan dengan penelitian yang dilakukan oleh Sumarti pada tahun 2020, bahwa terdapat hubungan antara jenis kelamin dan tingkat kecemasan $(\mathrm{p}=0,002)^{14}$ dan pada penelitian ini responden didominasi jenis kelamin perempuan.

Tenaga kesehatan dikhawatirkan akan menularkan COVID-19 kepada keluarga, dan tidak bisa sembarangan melakukan kontak dengan pasangan, anak atau anggota keluarga lainnya. Tenaga kesehatan yang merawat 
pasien Covid-19 sangat rentan terinfeksi virus. Mereka harus mempertaruhkan nyawa berurusan dengan pasien yang terinfeksi virus corona dengan risiko penularan yang sangat besar. Tidak hanya itu, mereka juga harus hidup terpisah dari keluarga selama berminggu-minggu untuk menghindari penularan virus yang lebih luas. ${ }^{15}$ Pada penelitian sejalan dengan peneltian yang dilakukan oleh Nura pada tahun 2021 bahwa tidak ada hubungan antara status pernikahan dengan tingkat kecemasan $(p=0,657)^{16}$ dan penelitian ini sebagian besar responden sudah menikah.

Masa bekerja merupakan rentang waktu yang telah ditempuh seseorang dalam bekerja atau lamanya tenaga kerja itu bekerja di suatu tempat. Pada umumnya, pekerja yang memiliki pengalaman kerja yang banyak terkadang tidak memerlukan bimbingan dibandingkan dengan pekerja yang pengalaman kerjanya lebih sedikit. Semakin lama seseorang bekerja pada suatu kerjaan maka akan semakin banyak pengalaman yang didapat oleh seseorang. ${ }^{17}$ Dalam penelitian ini terdapat hubungan antara masa kerja dengan tingkat kecemasan dan jumlah tingkat kecemasan paling banyak berada pada kelompok yang bekerja lama yaitu lebih dari 10 tahun. Hasil penelitian ini sejalan dengan penelitian yang dilakukan oleh Awaluddin pada perawat yang menunjukan bahwa adanya pengaruh antara masa kerja dengan tingkat kecemasan $(\mathrm{p}=0,040) .{ }^{17}$ Hal tersebut bisa jadi dikarenakan semakin lama masa kerja seseorang maka semakin tinggi tingkat kelelahan. Semakin lama seseorang bekerja maka muncul perasaan jenuh akibat pekerjaan yang monoton dan berpengaruh terhadap tingkat kelelahan yang dialami dan beban kerja yang didapat semakin lama bertambah.

\section{Kesimpulan}

Faktor-faktor yang berhubungan dengan tingkat kecemasan adalah usia $(\mathrm{p}=0,037)$, jenis kelamin $(\mathrm{p}=0,003)$, dan masa kerja $(p=0,023)$. Faktor yang tidak berhubungan dengan tingkat kecemasan adalah status pernikahan $(\mathrm{p}=0,830)$.

\section{Ucapan Terima Kasih}

Terima kasih kepada RSUD Dr. Moewardi Surakarta yang telah membantu peneliti dalam mengumpulkan data.

\section{Daftar Pustaka}

1. Republik Indonesia. Keputusan Menteri Kesehatan Republik Indonesia Nomor HK.01.07/MenKes/413/2020 Tentang Pedoman Pencegahan dan Pengendalian Corona Virus Disease 2019 (Covid-19).

2. World Health Organization (WHO). 2020. Coronavirus. Available from: https://www.who.int/healthtopics/corona virus.

3. Baloch S, Baloch MA, Zheng T, Pei X. 2020. The Coronavirus Disease 2019 (COVID-19) pandemic. Tohoku J Experimen Med. 250(4) : 271 - 278.

4. Susilo A, Rumende CM, Pitoyo CW, Santoso WD, Yulianti M, Herikurniawan H, et al. 2020. Coronavirus Disease 2019: Tinjauan Literatur Terkini. Jurnal Penyakit Dalam Indonesia. 7(1) : 45 - 67.

5. Pasal 1 angka 1 Undang-Undang Nomor 36 Tahun 2014 tentang Tenaga Kesehatan.

6. Shreffler J, Petrey J, Huecker M. 2020. The Impact Of COVID-19 on healthcare worker wellness: A Scoping Review. Western J Emergency Med. 21(5) : 1059 $-1066$.

7. Hanggoro AY, Suwarni L, Selviana, Mawardi. 2020. Dampak psikologis pandemi COVID-19 pada petugas tenaga 
kesehatan: a studi cross-sectional di Kota Pontianak. Jurnal Kesehatan Masyarakat Indonesia. 15(2) : $13-18$.

8. World Health Organization (WHO). 2021. Mental health. Available from: https://www.who.int/mental_health/who_ urges_investment/en/.

9. Vibriyanti D. 2020. Kesehatan mental masyarakat: mengelola kecemasan di tengah pandemi Covid-19. Edisi Khusus Demografi dan COVID-19. Jurnal Kependudukan.

10. Wijayanti W, Pohan V., Nugroho H. 2018. Hubungan persepsi pasien tentang penyakitnya dengan tingkat kecemasan di poliklinik rawat jalan Rumah Sakit Roemani Muhammadiyah Semarang. Manuscript, 151(2) :10-17.

11. Stuart GW, Laraia MT. 2007. Principlesand practice of psyhiatric nursing. (8thed). St.Louis: Mosby Year B.

12. Huang L, Wang Y, Liu J, Ye P, Chen $X$, $\mathrm{Xu} \mathrm{H}, \mathrm{Qu} \mathrm{H}$, Ning G. 2020. Factors influencing anxiety of health care workers in the radiology department with high exposure risk to Covid-19. Medical Science Monitor. 26.

13. Maryam, Kurniawan A. 2008. Faktorfaktor yang berhubungan dengan tingkat kecemasan orang tua terkait hospitalisasi anak usia toddler di BRSD RAA Soewono Pati. Jurnal Keperawatan. 1(2) : $38-56$.

14. Margaretha S., Effendy, C., Kusnanto, H., Hasinuddin M. 2020. Determinants Psychological Distress Of Indonesian Health Care Providers During Covid-19 Pandemic. Systematic Reviews in Pharmacy : A Multifaceted Review J The Field Pharm. 11(6): 1052-1059.
15. Fadli F, Ahmad A.S, Safruddin S, Sumbara S. Baharuddin R. 2020. Anxiety of health workers in the prevention and management of Covid-19 in Sidrap Regency. Unnes J Public Health. 9(2) : 91-97.

16. Vikawati NE, Nurrahma HA, Hardini IT, Hidajati EN. 2021. Tidak didapatkan kecemasan pada petugas kesehatan dalam menghadapi pandemi COVID-19. Syifa' Medika. 11(2), 116-125.

17. Awaluddin. 2020. Hubungan Pendidikan dan lama kerja dengan tingkat kecemasan perawat dalam penanganan pasien gawat darurat di RSUD Sawerigading Kota Palopo Tahun 2019. Jurnal Kesehatan Luwu Raya. 6(2):5-12. 